\title{
原著家鬼前脛骨筋の血流に及ぼす鍼刺激の影響
}

\author{
鶴 浩幸＼cjkstart松本 栜 \\ 明治鍼尒大学大学院 $\cdot$ 鍼尒臨床医学
}

\section{Effect of Acupuncture Stimulation on the Blood Flow of the Skeletal Muscles in Rabbits.}

\author{
Hiroyuki TSURU Tadasu MATSUMOTO \\ Clinical Medicine of Acpuncture and Moxibustion, Graduate School of \\ Acpuncture and Moxibustion, Meiji University of Oriental Medicine.
}

\section{A b s t r a c t}

To clarify the effect of acupuncture on the skeletal muscle blood flow, measurements of muscle blood flow by hydrogen gas clealance method were taken on the left anterior tibial muscles of thirty rabbits (weighing about 2.5 to $3.3 \mathrm{~kg}$ ) anesthetized with pentobarbital sodium $(35 \mathrm{mg} / \mathrm{kg}$, i.v.). Arterial blood pressure in the common carotid artery and body temperature were also measured.

Blood flow was measured 6 times every $10 \mathrm{~min}$. In the stimulation group, acupuncture needles were inserted into the center of the anterior tibial muscle before the third measurement and "sparrow pecking" was performed, then the needles were removed. In the denervation group, the sciatic nerve was cut to observe the influence of denervation on the effect of acupuncture.

In the stimulation group $(\mathrm{n}=12)$, a significant increase in blood flow to the muscles occurred after acupuncture stimulation, compared with the control group $(n=12)$. The increase in blood flow in the stimulation group was maintained until the final measurement. Arterial blood pressure and body temperature did not change.

The blood flow values in the second and third measurements were $18.1 \pm 2.2$, and $17.6 \pm 2.4$, respectively, in the control group, and $17.8 \pm 1.8$ and $25.9 \pm 2.2 \mathrm{ml} / \mathrm{min} / 100 \mathrm{~g}$ (mean \pm S.E.) in the stimulation group. The changes in blood flow values from the second to the third measurement were $-0.5 \pm 0.3 \mathrm{ml} / \mathrm{min} / 100 \mathrm{~g}$ in the control group, and $+8.2 \pm 2.0 \mathrm{ml} / \mathrm{min} / 100 \mathrm{~g}$ in the stimulation group. An increase in blood flow after acupuncture stimulation also occurred in the denervation group $(n=3)$,

Despite there being no change in arterial blood pressure. blood flow was increased after acupuncture stimulation, and the increment of blood flow after acupuncture stimulus was also observed in the denervation group. Therefore, the increment of blood flow seems to have been caused by vasodilation of the blood vessels induced by axon reflex.

Key words : blood flow, acupuncture, muscle, hydrogen gas clearance method, muscular pain 


\section{1. 緒言}

鍼治療は消炎・鎮痛や筋痙縮の緩和等を目的に 行われることが多く、その治療効果には刺鍼によ る血流改善も深く関与しているものと推測されて (る1-3)。鍼炎刺激が皮膚血流4-7) や内臓血流，神 経血流等8-12) の改善作用を有することは報告され てきている。筋の血流動態に及ぼす銊尒の影響に 関しては、ヒトを対象に深部温測定 ${ }^{13)}$ やストレン ゲージプXチスモグラフイー14) 等の測定によって 筋血流の変化を推定した報告はあるが、筋血流量 を直接定量的に測定し，しかも体温コントロール、 経時的血圧測定下で鍼刺激の影響を詳細に検討し た研究報告はみられない。体温と血圧は末梢血流 と密接な関係があり、血流変動時の体温と血圧の 動態が明らかでなければ鍼刺激の影響を明確に論
じることは難しい。そこで本研究では、家兔を用 いて体温を一定に保持した血圧連続測定下で前脛 骨筋の血流量を電解式組織血流計（電解式水素ク リアランス法）を用いて測定し、筋血流に対する 鍼刺激の影響について検討した。

\section{2. 方法}

\section{1 ）実験動物}

実験には、明暗周期 $12 ； 12$ 時間で飭および水は 24 時間自由摂取、室温 $24 \pm 1{ }^{\circ} \mathrm{C}$ の環境下で飼育し た日本白色家鬼30羽（雌、体重2.5 3.3Kg）を用 い、前脛骨筋を被検筋とした。

\section{2 ) 測定方法}

家鬼を、ベントバルビタール $(35 \mathrm{mg} / \mathrm{kg})$ によ

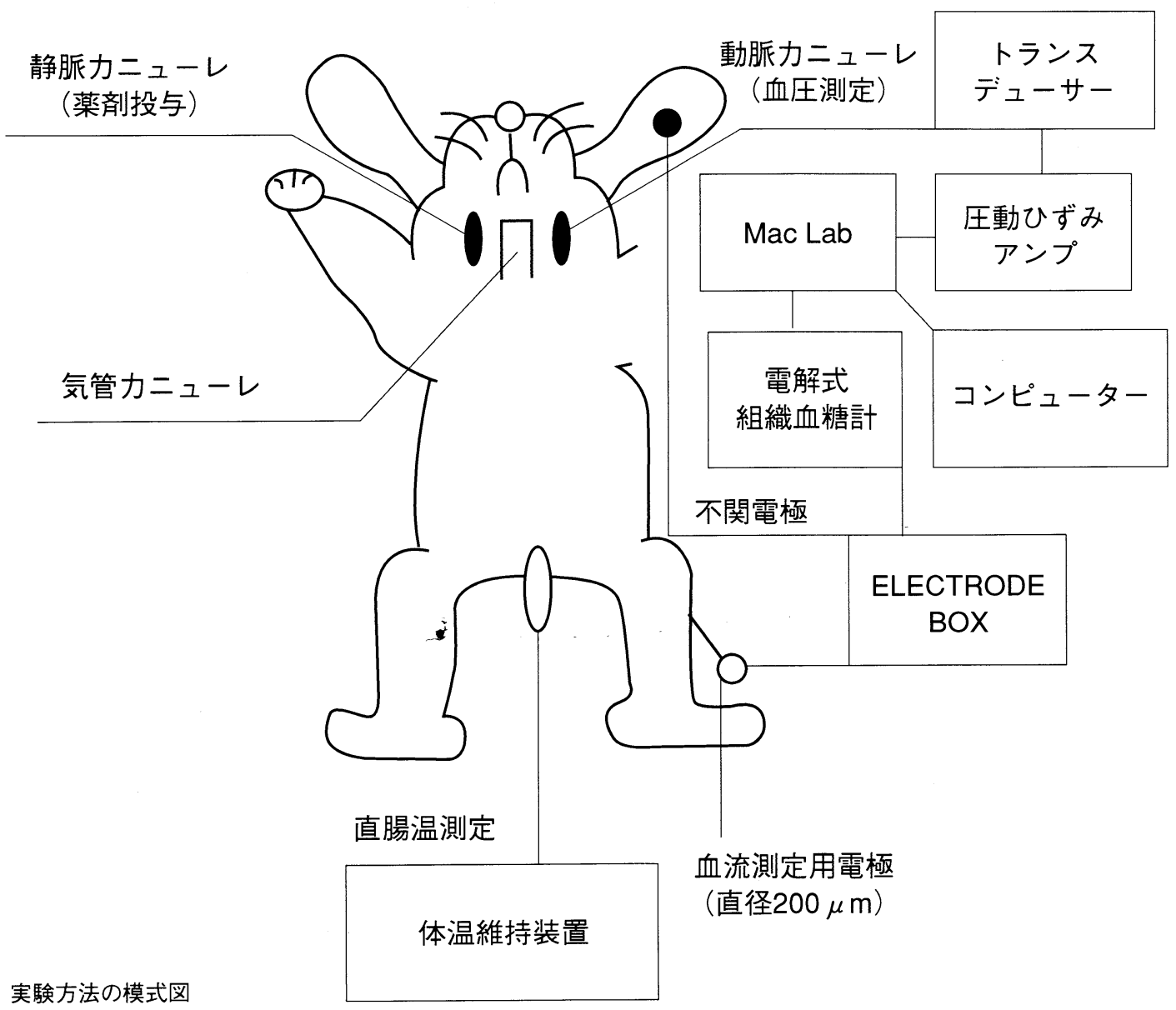


る耳静脈麻酔後、自家製固定台に背臥位で固定し た（図 1)。直腸温をモニターしながら、体温維 持装置（MUROMACHI KIKAI 社製ANIMAL BLANKET SYSTEM MK-900）により体温を一定 に保持した $\left(39.4 \pm 0.3^{\circ} \mathrm{C}\right)$ 。家鬼の陑部を切開し て気管カニューレおよび薬物投与のための静脈カ ニューレを挿入し、次いで血圧測定のために、へ パリンナトリウムと生理食塩水の混合液を入れて 圧力トランスジューサー（Statham 社 P-23Db）に 接続したカニューレを総澒動脈に挿入した。血圧 データは、圧動ひずみアンプ (三栄測器、STRAIN AMPLIFIER 6M62）により増幅し、Mac Lab（バ イオリサーチセンター) を介してコンピューター (Apple社 Macintosh 5300CS) に記録した。不関 電極は、耳介内面に装着した。

筋血流量は、電解式組織血流計（バイオメデイ カルサイエンス、 R B F - 22) を用いて測定し、 得られたクリアランスカーブは、血圧とともに Mac Lab を介してコンピューターに記録した。前 脛骨筋の下腿部の上方から約 $1 / 2$ の皮膚と筋膜を約 $5 \mathrm{~mm}$ 切開し、血流測定用白金電極（バイオメデ

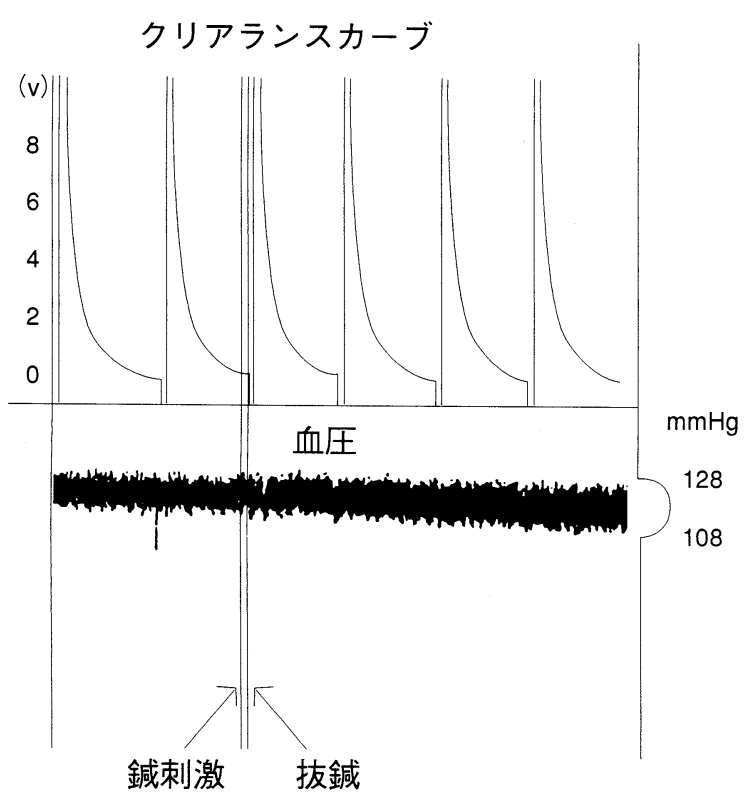

図2. クリアランスカーブおよび血圧の記録例 電解式水素クリアランス法による1例のクリアランスカー ブと血圧の記録を示す。
イカルサイエンス、BE-NS、直径 $200 \mu \mathrm{m})$ を約 $45^{\circ}$ の角度で上方に向けて約 $3 \mathrm{~mm}$ 挿入した（図 $2)$ 。なお、測定電極の周囲の血液凝固と気泡の 付着を防ぐためへパリンを500単位/ $\mathrm{kg}$ 静注し た ${ }^{15,16)}$ 。測定条件は、電解電流 $5 \mu \mathrm{A}$ 、電圧 $0.6 \mathrm{~V}$ 、 電解時間30sec、室温 $25 \pm 1{ }^{\circ} \mathrm{C}$ で行った。まず、対 照群 $(n=12)$ は、刺鍼せずに10分間隔で 6 回測 定を行った。銊刺激群 $(\mathrm{n}=12)$ は、無刺激で 2 回測定後、3 回目の測定直前に鍼刺激を行い、そ の後 4 回測定をした。

また、鍼刺激の筋血流に対する上位中枢を介す る反射の関与をみるため、坐骨神経切断後の家兔 で測定を行った。すなわち、坐骨神経を切断して から無刺激で 6 回測定したものと、2 回測定後に 銊刺激を行い、その後 4 回測定したものを 3 例ず つで行った。

なお、実験の最後に、15\%塩化カリウム液（1ml /kg）を静注し、血圧モニターの波形で死亡を確認 した後にクリアランスカーブを描かせて死後の半 減期を求めた。実験終了後には電極の位置を確認

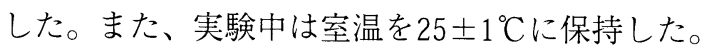

\section{3）血流量の算出方法}

前脛骨筋から得られたクリアランスカーブの電 圧值を 10 秒毎に片対数方眼紙にプロットし、半減 期を求めた。なお今回の実験で用いた組織血流計 は電解式のため、局所にのみ水素ガスを発生させ る原理上、家鬼生存中の半減期には血流のない状 態での拡散による值も加味されているので、下記 のKoshuの計算式により血流量 $(\mathrm{F})$ を算出した17)。 $\mathrm{F}=69.3(1 / \mathrm{Tc}-1 / \mathrm{Td})(\mathrm{ml} / \mathrm{min} / 100 \mathrm{~g})$

$\{\mathrm{Tc}$ : 生存中の半減期 $\mathrm{Td}$ : 死後の半減期\}

\section{4 ）鍼刺激の方法}

鍼刺激は、全て直径 $0.24 \mathrm{~mm}$ のステンレス銊を用 い血流測定用白金電極の上方 $1 \mathrm{~cm}$ の部位に前脛 骨筋に対して約 $45^{\circ}$ の角度で斜め下方に約 $1 \mathrm{~cm}$ 刺 入し、約 $5 \mathrm{~mm}$ の振幅で10回雀豚した後すぐに抜 銊した。

\section{5) 上位神経切断の方法}

殿部に約 $3 \mathrm{~cm}$ の切開を施し、坐骨神経を無傷露 
表 1．対照群および鍼刺激群の家鬼前脛骨筋血流量の推移

\begin{tabular}{|c|c|c|c|c|c|c|c|}
\hline \multicolumn{2}{|c|}{$\begin{array}{l}\text { Order of measurement } \\
\qquad \text { (Time : min.) }\end{array}$} & $\begin{array}{l}\text { First } \\
(0)\end{array}$ & $\begin{array}{l}\text { Second } \\
\text { (10) }\end{array}$ & $\begin{array}{l}\text { Third } \\
(20)\end{array}$ & $\begin{array}{l}\text { Fourth } \\
(30)\end{array}$ & $\begin{array}{l}\text { Fifth } \\
(40)\end{array}$ & $\begin{array}{l}\text { Sixth } \\
(50)\end{array}$ \\
\hline \multirow{3}{*}{$\begin{array}{c}\text { Blood flow } \\
\mathrm{ml} / \mathrm{min} / 100 \mathrm{~g} \\
\text { (Mean } \pm \text { S.E.) }\end{array}$} & $\begin{array}{l}\text { Control } \\
(n=12)\end{array}$ & $\begin{array}{l}20.2 \\
\pm 2.3\end{array}$ & $\begin{array}{l}18.1 \\
\pm 2.2\end{array}$ & $\begin{array}{l}17.6 \\
\pm 2.4\end{array}$ & $\begin{array}{l}16.8 \\
\pm 2.3\end{array}$ & $\begin{array}{l}16.8 \\
\pm 2.4\end{array}$ & $\begin{array}{c}17.0 \\
2.2\end{array}$ \\
\hline & & \multicolumn{2}{|c|}{ before acupuncture } & \multicolumn{4}{|c|}{ after acupuncture } \\
\hline & $(n=12)$ & $\begin{array}{l}18.1 \\
\pm 1.6\end{array}$ & $\begin{array}{l}17.8 \\
\pm 1.8\end{array}$ & $\begin{array}{l}25.9 \\
\pm 2.2\end{array}$ & $\begin{array}{l}26.9 \\
\pm 1.9\end{array}$ & $\begin{array}{l}24.5 \\
\pm 2.4\end{array}$ & $\begin{array}{l}22.7 \\
\pm 2.7\end{array}$ \\
\hline
\end{tabular}

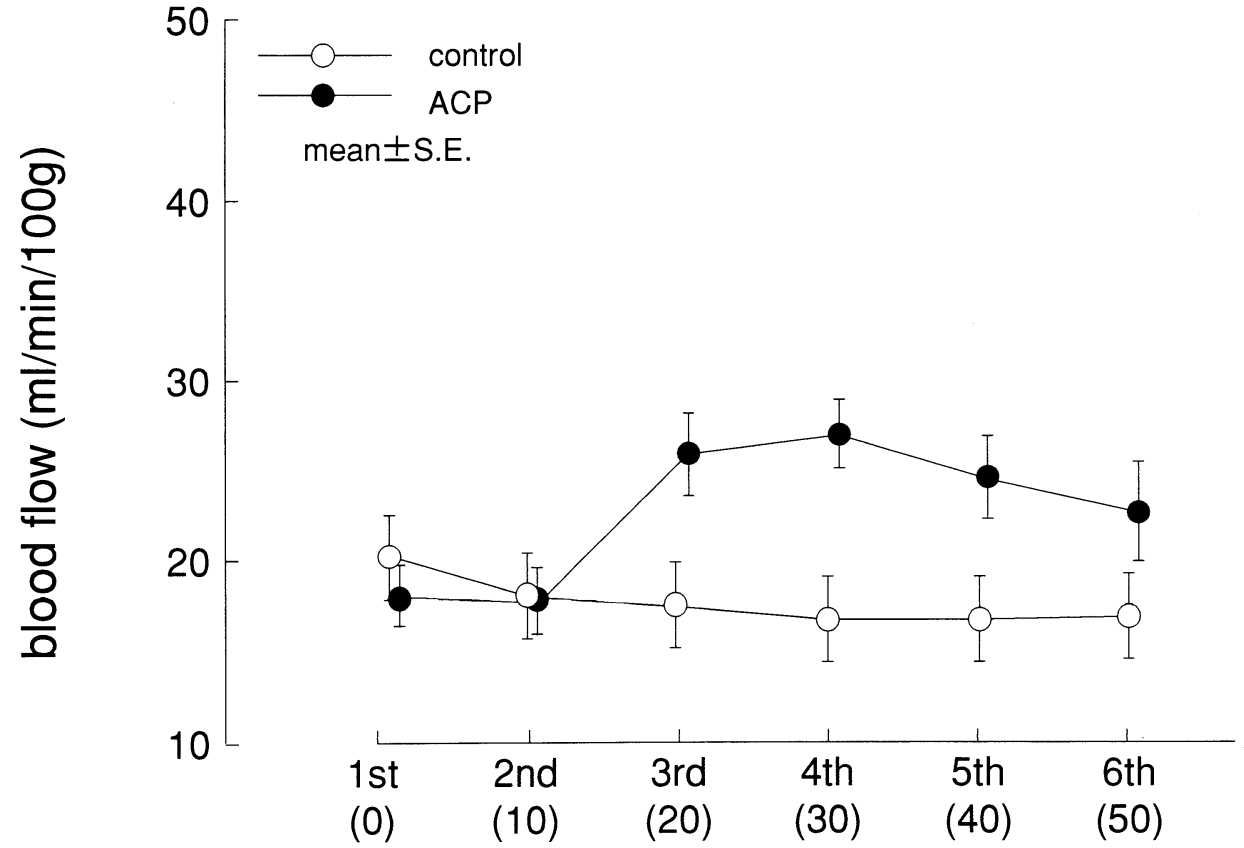

図3. 対照群および鍼刺激群の前脛骨筋血流量の推移

血流量は平均土標準誤差で表した。対照群 $(n=12)$ は徐々に減少する経過を示したが、鍼刺激群 $(n=12)$ は刺激後に血流 の増加を示した。2 群の経時的変化のパターンに有意な差が認められた（Huynh Feldt 補正後の二元配置分散分析法： p< 0.00004）。また、対照群と銊刺激群の間で第 3 回目以降に有意差が認められた（補正Tukey法による多重比較法：第 3 ～ 5 回 目 $p<0.01$ 、第 6 回目 $p<0.05)$ 。

出した後、損傷電流による筋収縮が起こらないよ うにパラフィンを敷き、 $2 \%$ キシロカインを切断 部に塗布した後に坐骨神経を切断した。周囲の乾 燥を防ぐため閉創し、生理食塩水で湿らせた綿花 を置いた。

\section{6 ）結果の表示及び統計処理方法}

求めた対照群、鍼刺激群の血流量を平均士標準 誤差で表した。効果判定の有意差の検定には二元 配置分散分析法、多重比較法を用い（スリースカ ンパニー社製 Macintosh 用統計解析ソフト Statistica 
表2. 経時の分散分析表

\begin{tabular}{|c|c|r|r|r|c|c|c|c|}
\hline 効果 & 効果df & 効果ms & 誤差df & 誤差ms & F值 & P值 & $\begin{array}{c}\text { Huynh- } \\
\text { Feldt } \varepsilon\end{array}$ & 補正P值 \\
\hline Group & 1 & 858.0017 & 22 & 279.2859 & 3.0721 & 0.0936 & - & - \\
\hline Time & 5 & 55.5507 & 110 & 15.9678 & 3.4793 & 0.0059 & 0.5434 & 0.00004 \\
\hline G. ${ }^{*}$ T. & 5 & 146.9854 & 110 & 15.9678 & 9.2051 & 0.0000 & 0.5434 & 0.00004 \\
\hline
\end{tabular}

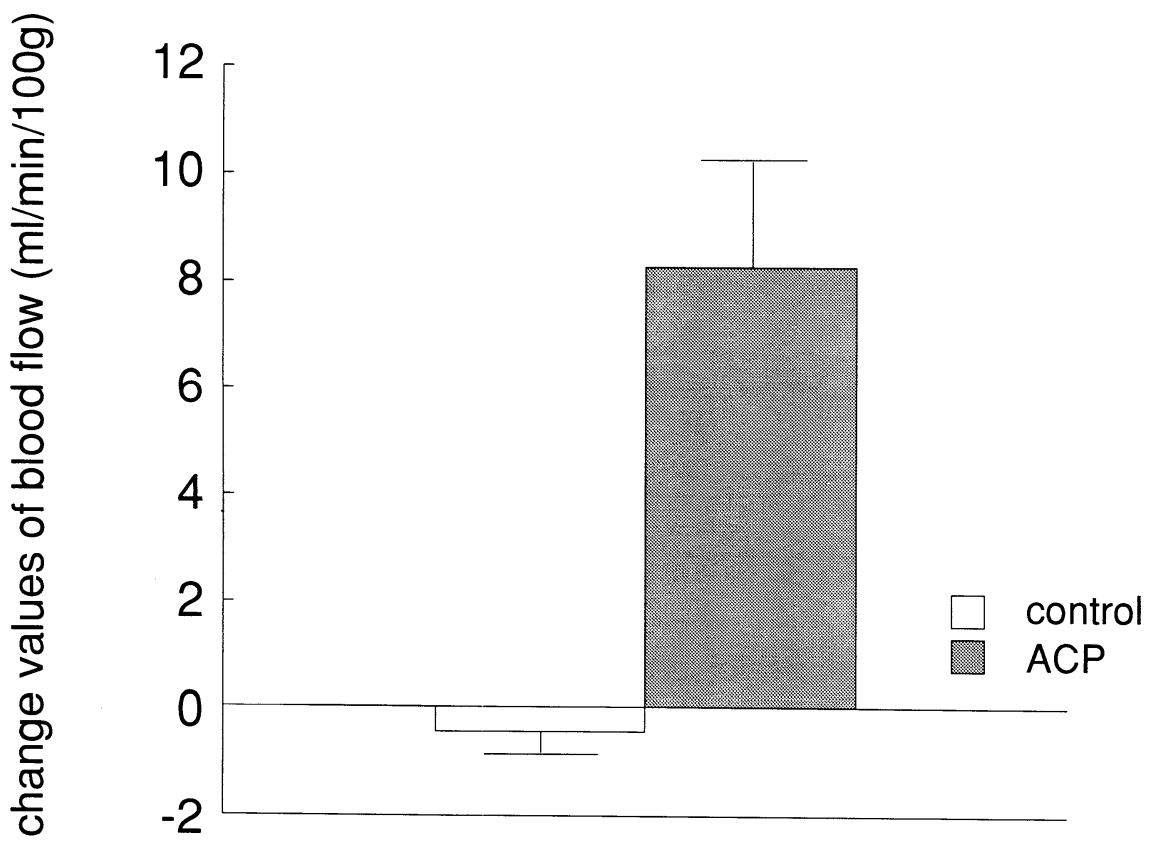

図4. 第 2 回目に対する第 3 回目測定時の前脛骨筋血流の変化量 血流量は平均土標準誤差で表した。

4.1J )、 $\mathrm{p}<0.05$ ののを有意差ありとした。

\section{3. 結果}

1 ）対照群および鍼刺激群の血流変化

図 2 に1例のクリアランスカーブと血圧の記録 を示した。血圧はいずれの実験においても著明な 変動を示さなかった。対照群 $(n=12)$ と銊刺激 群 $(\mathrm{n}=12)$ の筋血流量の変動を表 1 と図 3 に示 した。2 群の各時点の值の分散は等分散であった (バーレット $\chi 2$ 值 $=4.6193$ 、自由度 $=11 、 \mathrm{p}<$ 0.94482 )。

対照群の血流量は、第 1 回目の測定で20.2土 $2.3 \mathrm{ml} / \mathrm{min} / 100 \mathrm{~g}$ (mean \pm S.E., 単位は以下 $\mathrm{ml}$ で表
わす。）であったが、 2 回目以降は $18.1 \mathrm{ml} 、 17.6 \mathrm{ml}$ $16.8 \mathrm{ml} 、 16.8 \mathrm{ml}$ とやや減少傾向を示し、最終の 6 回目測定時には $17.0 \mathrm{ml}$ となった。一方、鍼刺激群 の血流量は、第 1 回目測定時に18.1 $1.6 \mathrm{ml}$ であ り、2 回目には $17.8 \mathrm{ml}$ にや減少したが、3 回目 には $25.9 \mathrm{ml} 、 4$ 回目には $26.9 \mathrm{ml}$ と増加し、その後 は、 $24.5 \mathrm{ml} 、 22.7 \mathrm{ml}$ 減少傾向を示したものの、 最終測定時にも対照群よりも高值を保持していた。 なお、血圧は 6 回の測定中ほぼ一定であった。 また、直腸温は $39.4 \pm 0.3^{\circ} \mathrm{C}$ 安定しており、鍼刺 激による変化はみられなかった。

対照群と鍼刺激群の血流量の経時的変化につい て、Huynh Feldt の補正下で二元配置分散分析法 
により検定を行った結果、表 2 のように経時的変 化のパターンに有意な差が認められた（ $\mathrm{p}<$ 0.00004)。また、補正 Tuky 法による多重比較の 結果では、対照群と鍼刺激群の第 3 回目測定以降 (銊刺激後) に有意差が認められた（3 回目、4 回目および 5 回目 : $p<0.01 、 6$ 回目 $: p<0.05)$ 。

なお、2 回目に対する 3 回目測定時の变化量は、 対照群がー0.5 $00.3 \mathrm{ml}$ あ゙るのに対し、銊刺激群 は+8.2 $\pm 2.0 \mathrm{ml}$ であった（図 4 )。また、鍼刺激群 で 2 回目または 3 回目測定時に $5 \mathrm{ml}$ 以上の増加を 示したのは、12例中 8 例 $(67 \%)$ であった。

\section{2 ) 坐骨神経切断群の血流変化}

図 5 に、坐骨神経を切断して無刺激で 6 回の血 流量測定のみした群（坐骨神経切断・無刺激群、 $\mathrm{n}=3$ ) と鍼刺激を行った群（坐骨神経切断・銊 刺激群、 $\mathrm{n}=3$ ) の平均血流量の推移を示した。 無刺激群では経時的な変動はみられなかったが、 銊刺激群では鍼刺激以降（3 回目測定時以降）に
血流増加が示された。個体別にみると、無刺激群 では血流は 3 例ともほぼ一定で変動を示さなかっ たが、鍼刺激群では 3 例ともに刺激以降の 3 回目 （2例）あるいは 4 回目測定時（1例）から血流 増加が起こった。

\section{4. 考察}

1 ）血流量の測定方法について

組織血流測定法には加熱熱電対法18,19)、プレチ スモグラフィー20)、レーザードップラー法10,21)、 さらにガスを用いた局所でのクリアランスにより 求める方法などがある。しかし、加熱熱電対法で は筋血流の変化を定量的に直接とらえることがで きず、プレチスモグラフィーでは選択的に筋組織 の血流のみを測定することができない。これらの 方法に比べて水素クリアランス法は、直接筋血流 量を測定することができる。

水素ガスクリアランス曲線から組織局所血流量 を求める方法には、1964年 Aukland らにより提唱

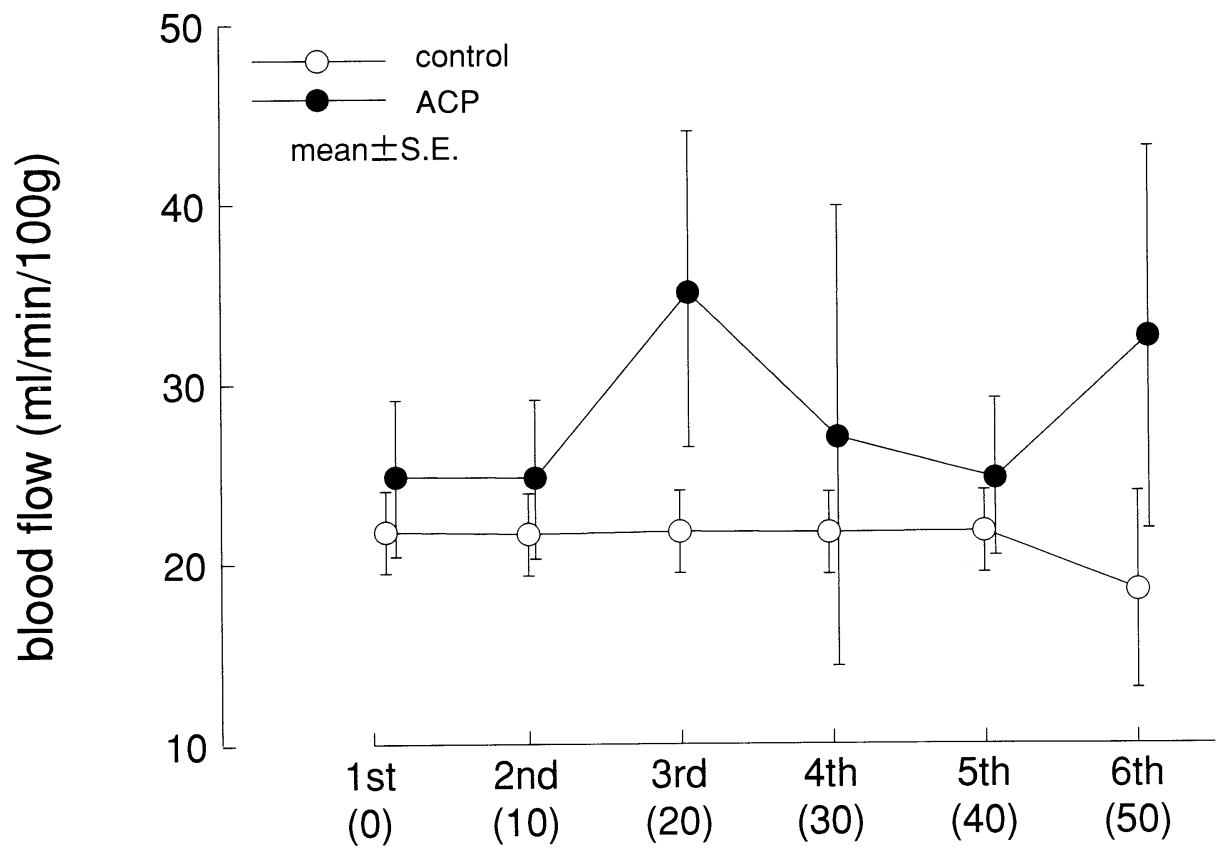

図5. 坐骨神経切断群の前脛骨筋血流量の推移

血流量は平均土標準誤差で表した。無刺激 $(n=3)$ は 3 例ともに変動を示さなかったが、鍼刺激群 $(\mathrm{n}=3)$ は 3 例ともに血 流の増加を示した（3 回目測定時以降：2 例、4 回目測定時以降：1例）。 
された吸入法22) と、1974年 Stosseckらにより提唱 された電気分解法 23$)$ の 2 通りの方法がある。いず れも水素ガスが洗い流される時に発生する微小電 流を、局所に挿入された電極により感知し、その 電流の減衰曲線から計算して血流量を求めるもの であるが、水素ガスの吸入は生体への影響が少な くない。本実験では吸入法に比べて危険性が少な く、比較的短時間で反復測定でき、生体への影響 が少ないという利点をもつ電解法を用いたので、 吸入法による水素ガスの影響は排除できたものと 考える。

\section{2 ）対照群の筋血流量について}

家鬼前脛骨筋血流量は、吸入式水素クリアラン ス法を用いたものでは、Mishraら ${ }^{24)} は 8.2 \pm 1.7 \mathrm{ml}$ 、 竹宮ら ${ }^{25)}$ は21.3 $\pm 1.8 \mathrm{ml}$ を報告し、電解式水素クリ アランス法では宮森ら ${ }^{15)}$ は33.9 $\pm 13.9 \mathrm{ml}$ 報告し ている。本実験で得た対照群と刺激群の測定值

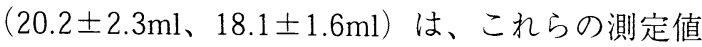
から大きく逸脱するものではなく、中間的な值で あるので、前脛骨筋の血流量としてはほぼ妥当な 值であると考える。

また、対照群の血流量は時間の経過とともにや や減少傾向を示したが、これは麻酔の覚醒にとも なう交感神経の緊張によって生じた血管緊張の回 復による血流減少や、筋内に測定電極を刺入する ことによって生じた軸索反射等による一時的な血 管拡張後の回復過程での血流減少の表われである 可能性が考えられる。坐骨神経切除後では血流変 化がみられなかったことも、対照群の血流減少が 麻酔の覚醒にともなう交感神経の緊張回復と関連 していることを示唆している。

\section{3 ）鍼刺激による筋血流の変動について}

今回の実験において鍼刺激群の血流量が増加を 示した。これは、鍼刺激によって筋の血管拡張が 起こったことを表わしており、筋肉痛や肩こり、 五十肩等の運動器系疾患に筋血流改善の目的で鍼 を行うことの妥当性を示唆するものであると考え る。そして、鍼刺激による総澒動脈圧の変化がほ とんどみられなかったことから全身性に血管拡張 が生じるのではなく、刺激を行った筋の局所の血
管拡張が起こったものと考えられる。さらに、坐 骨神経を切断しても鍼刺激後に筋血流の増加がみ られたことから、刺鍼後の血流増加は、中枢を介 する反射性の自律神経による血管拡張の関与は少 なく、感覚神経内での軸索反射による血管拡張の 可能性が高いと考えられる。木下26) は、モルモッ トの腓腹筋において強縮刺激後の疲労筋への施鍼 によって短縮高の回復の促進がみとめられ、しか もこの現象は支配神経を切除しただけでは影響を 受けなかったので、これは鍼刺激で筋血流の増加 が起こったことが原因であり、血流増加は、軸索 反射による血管拡張が関与していると推測してい る。桑澤ら 27)も強縮刺激後の疲労筋への施鍼によ って短縮高の回復促進がみられたが、CGRPを注 入しても施針と同様の効果が出現し、この現象は アトロピンで遮断されたことから、感覚神経にお ける軸索反射とコリン作働性交感神経の関与によ る血管拡張が起こり、血流が改善されたと推測し ている。本研究では自律神経遮断薬によるデー夕 がないため、コリン作働性交感神経の関与につい ては言及できないので、今後検討する必要がある と考える。

\section{5. まとめ}

筋血流に対する鍼刺激の影響を検討するために、 体温コントロール、血圧連続測定下で、麻酔下家 兔の前脛骨筋血流量を電解式組織血流計を用いて 測定し、以下の結果を得た。

1) 対照群においては、筋血流量は測定ごとにや や減少傾向を示した。

2 ) 鍼刺激群においては、刺激後に血流量の増加 がみられた。

3 ）坐骨神経を切断した後に鍼刺激を行っても筋 血流の増加がみられたことから、筋血流の増加 には、春髄以上の上位中枢を介する反射性の血 管拡張の関与は少なく、主に軸索反射による血 管拡張が関与しているものと考えられた。

4 ）運動器疾患に対する鍼刺激の効果には、筋血 流の改善が関与していることが示唆された。

\section{謝 辞}

稿を終えるにあたり、多大なるご助言を頂いた 
明治鍼尒大学第三生理学教室・川喜田健司教授お よび岡田薫助手, ならびに種々ご協力頂いた東洋 医学教室・高橋則人助手に深謝いたします。

\section{参考文献}

1）木下晴都：局所疼痛に対する針作用の実験的 研究 1 : 皮膚温、筋肉温、脈波から検した局 所疼痛に対する針尒の作用機序, 昭医誌, 41(2)；147〜156,1981.

2 ) 石丸圭荘, 松本 勅, 矢野 忠ほか：アレ ン・ライトテスト時の指尖容積脈波に及ほす 斜角筋刺鍼の効果, 全日本銊尒学会雑誌, 41 (4)；366～369,1991.

3 ) 伊藤 譲, 松本 勅: 家鬼前脛骨筋の筋張 力に対する置鍼の影響, 全日本鍼炎学会雑 誌, 46(4)；326～333,1996.

4) 松本 勅: 東洋系物理療法のサーモグラフィ による研究. 一 (1) 銊炎治療で取り扱った下肢疼 痛症例のサーモグラフィ所見, 東洋医学とぺ インクリニック， $8(2) ； 1 ８, 1978$.

5 ) 松本 勅: 東洋系物理療法のサーモグラフィ による研究. 一 (2) 銊尒治療で取り扱った下肢冷 え症例のサーモグラフィ所見, 東洋医学とぺ インクリニック，8(4)；9〜14,1978 .

6 ) 松本 勅: 澒肩部銊刺激の上肢血液循環に及 ぼす影響, 東洋医学とペインクリニック, 10(3)；121 125,1980.

7 ) 篠原昭二, 松本 勅, 西牧紀子ほか: 雀豚, 銊通電および S S P 刺激の肩甲上部皮膚・筋 血流に及ぼす影響, 全日本鍼尒学会雑誌, 32(2)；17〜23,1982.

8 ）松本 勅, 池内隆治：家忽胃壁血流に対する 鍼刺激の効果, 明治鍼炎医学, $12 ; 7 \sim 12$, 1993 .

9 ) 松本 勅, 池内隆治: 家鬼胃壁血流に対する 尒刺激の効果, 全日本鍼炎学会雑誌, 44(2); $170 \sim 175,1994$.

10）石崎直人, 山村義治ほか：胃粘膜血流に及ほ す鍼刺激の効果, 明治鍼尒医学, $11 ; 1$ 9,1993.

11）松本 勅, 兵藤正義：Acupuncture（ハリ）と 血流，循環制御， 6 (4)；469 480,1985.
12）山口大輔, 松本 勅：家鬼腰部鍼刺激が坐骨 神経幹の血流に及ぼす影響, 全日本鍼炎学会 雑誌, 47(3)；165～172,1997.

13）松本 勅, 森本安夫, 川井正久ほか：鍼刺激 の下肢深部温および皮膚温に及ぼす影響，自 律神経雑誌，26(3・4)；97～101,1980.

14）松本 勅, 篠原昭二, 池内隆治ほか: 鍼刺激 によるヒ卜下腿筋血流の改善, 明治銊尒医学, $6 ; 83 \sim 87,1990$.

15）宮森邦夫：家鬼下腿圧迫下における筋膜区画 内圧, 筋血流量および末梢血流量の関係, 金 沢大学十全医学会雑誌, 97(4)：883 897, 1988.

16）篠田耕三：電気分解式水素クリアランス法に よる骨髄内局所血流量の測定 : 金沢大学十全 医学会雑誌, 94(4)；678～688,1985.

17) Kenji Koshu,M.D., Kazuyo Kamiyama,M.D., Nobuo Oka,M.D., et al: Measurement of Regional Blood Flow using Hydrogen Gas Generated by Electrolysis, Stroke , 13(4) ; 483 $\sim 487,1982$.

18) MICHIO ARAI AND HIROYUKI ENDOH : Blood Flow through Human Skeletal Muscle during and after Contraction, Tohoku J. exp. Med., $114 ; 379 \sim 384,1974$.

19) A MCPHERSON, JOHN SCALES and L.H. gordon: A METHOD OF ESTIMATING QUALITATIVE CHANGES OF BLOOD FLOW IN BONE, THE JOURNAL OF BONE AND JOINT SURGERY , 43B ; 791 799,1961.

20）土光荘六, 勝村達喜 : Mercury Strain Gauge法 による血流測定について, 脈管学, $21 ; 327$ ３30,1981.

21）小山冨康, 三品博達, 朝倉利光：レーザー・ ドップラー血流計, 臨床科学, $13 ; 1197$ 1202,1977.

22) Aukland K, Bower B.F., Berliner R.W. : Measurement of Local Blood Flow with Hydrogen Gas, Circ. Res., 14 ; 164 187,1964.

23) Klaus Stosseck, Dietrich W. Lubbers, and Norbert Cottin : Determination of local Blood Flow(Microflow) by Electrochemically 
Genarated Hydrogen, Pflugers Arch., 348 ; 225

$\sim 238,1974$.

24) Mishura S.K., and Haining J.L, : MEASUREMENT OF LOCAL SKELETAL MUBCLE BLOOD FLOW IN ANIMALS BY THE HYDROGEN ELECTRODE TECHNIQUE, MUSCLE and NERVE, 3 ; $285 \sim 288,1980$.

25）竹宮 隆, 橋羽裕規男, 橋爪和夫ほか: 水素 ガスクリアランス法による家鬼後肢骨格筋と
その腱の組織血流について, 体力科学, 31 , 41〜 50, 1982.

26）木下晴都：局所疼痛に対する針作用の実験的 研究 2 : 強縮後の短縮高回復過程に及ぼす 置鍼の作用，昭医誌，41(4)；393～403,1981.

27）桑澤二郎, 佐藤三千雄, 武重千冬: 局所疼痛 に対する針作用の実験的研究 昭医誌，47(1); $81 \sim 88,1987$.

\section{要旨}

骨格筋血流に対する鍼刺激の効果を明らかにするため、ペントバルビタールで麻酔した家兔30羽（体重 約2.5３.3kg）の前脛骨筋の血液を、水素クリアランス法によって測定した。総頚動脈の動脈圧と体温も 同時に測定した。

血流は10分おきに 6 回測定した。鍼刺激群においては、第 3 回目の測定の前に.鍼を前脛骨筋の約中央 に刺入し、雀豚術を行ってから抜鍼した。さらに、除神経群では、鍼の効果に対する除神経の影響を観察 するために坐骨神経を切断した。

刺激群（n=12）においては、鍼刺激後に対照群（n=12）に比して血流の有意な増加が起こった。刺激群の 血流増加は最終の測定時まで持続した。動脈圧と体温は変化しなかった。

第 2 回目と第 3 回目の測定時の血流值は、対照群ではそれぞれ $18.1 \pm 2.2 ， 17.6 \pm 2.4 \mathrm{ml} / \mathrm{min} / 100 \mathrm{~g}$ (平 均土標準誤差)、刺激群ではそれぞれ $17.8 \pm 1.8 ， 25.9 \pm 2.2 \mathrm{ml} / \mathrm{min} / 100 \mathrm{~g}$ であった。第 2 回目に対する第 3 回 目の測定の血流の変化量は、対照群は $-0.5 \pm 0.3 \mathrm{ml} / \mathrm{min} / 100 \mathrm{~g}$ 、刺激群は $+8.2 \pm 2.0 \mathrm{ml} / \mathrm{min} / 100 \mathrm{~g}$ であった。銊 刺激後の血流増加は、除神経群においても起こった $(\mathrm{n}=3)$ 。

動脈圧は変化を示さなかったにも拘らず、血流は鍼刺激後に増加し、また、鍼刺激後の血流増加は除神 経群においても起こったのことから、鍼刺激後の血流増加は軸索反射によって引き起こされた筋の血管拡 張によって生じたものと思われた。 